\title{
GRIT at Panmunjom? How to Cope with Conflict in Northeast Asia
}

\author{
Walter Clemens
}

\begin{abstract}
A medley of theories proffers guidance on how to explain conflict behavior and how to resolve conflicts in Northeast Asia. Some theories combine description and prescription. The key issue is whether actors claim values as in a zero-sum contest or try to create values that enhance the objectives of each key player. This paper focuses on the theory of GRIT-graduated reciprocation in tensionreduction-advanced by psychologist Charles E. Osgood in 1962. The paper summarizes what Osgood saw as the key elements of a GRIT strategy and the major pitfalls if would have to overcome. To what extent have the major actors in Northeast Asia attempted some version of GRIT in past decades? Why have their efforts in this direction foundered or even backfired? Regardless of past experiences, might a strategy of "true" GRIT help to ameliorate conflicts today and tomorrow? What can we learn from earlier versions of GRIT practiced by the United States and USSR, the USA and China? Relations between North Korea and other key actors would probably benefit from a mutual gain orientation, but can GRIT bring about such an orientation or does its success depend on a preexisting disposition to search for positive-sum outcomes?
\end{abstract}

Key Words: conflict resolution, North Korea, GRIT, value-creating, interdependence

N ortheast Asia takes its place in the wider debate about the roles played in evolution by zero-sum struggle and by cooperation (see, for example, Minelli and Fusco 2008; Clemens 2013). How should the leading actors-Americans, Chinese, Japanese, Russians, North and South Koreans-cope with the winnertake-all orientations that often clash on and around the Korean peninsula? Should the United States and its partners try to cooperate with a regime believed to abuse its own people and to threaten world peace? ${ }^{1}$ The Pyongyang regime's frequently bellicose words and deeds raise doubts whether any outsiders could reach any accommodation with Pyongyang regarding issues of high politics (security issues such as weapons and boundaries) or even "low" politics (trade,

*Walter C. Clemens, Jr. (walter.clemens@gmail.com) is a Professor Emeritus of Political Science, Boston University, and Associate, Harvard University, Davis Center for Russian and Eurasian Studies. He wrote Getting to Yes in Korea (Boulder CO: Paradigm Publishers and Seoul: Hanul, 2010) and Complexity Science and World Affairs (Albany: State University of New York Press, 2013).

The author thanks Charles K. Armstrong, Terence Roehig, and Yurim Yi for suggestions and encouragement; also three incisive reviewers for this journal. 
the environment, culture). For a fragile if not failing state, nearly everything is high politics-from energy to human rights.

To understand and respond to the dangers to peace and to human dignity in the region, we need to draw on history, social science, and philosophy. Let us review several theories that help us to understand conflict and that suggest ways to manage if not resolve differences between the United States and DPRK. ${ }^{2}$ The lessons, if any, can be adopted and adapted by all the concerned players, not just by Washington and Pyongyang? If North Korean policy is monolithic and inexorably zero-sum in its orientation, efforts at conciliation are bound to be futile. ${ }^{3}$ But one cannot know what is "inexorable" without serious testing and leaders have been known to change their minds.

Some analysts question whether laws, values, and theories endorsed by Westerners apply also to Asia, but Singapore's Ambassador-at-Large Tommy Koh is a poster for universality. His labors show that some diplomatic techniques are useful across cultures, modulated to fit the particulars of each actor. ${ }^{4}$ In April 2014 Koh received Harvard University's "Great Negotiator Award" for his work as chief negotiator for the U.S.-Singapore Free Trade Agreement, the Third UN Conference on the Law of the Sea, and the UN Rio Earth Summit (Sebenius and Green 2014). Another transnational diplomat is Ban Ki-moon, former ROK Minister of Foreign Affairs and Trade, elected in 2007 and reelected in 2011 to serve as Secretary General of the United Nations.

${ }^{1}$ The UN Human Rights Council Commission of Inquiry reported in March 2014 on human rights abuses in the DPRK. The UN Security Council has five times condemned the missile and nuclear weapon tests of the DPRK.

${ }^{2}$ Theories about how to negotiate and resolve differences are nested within broader approaches to the study of international relations. These approaches include realist, liberal, game theory, constructivist, post-modern/critical theory, historical materialist/world system, feminist, biopolitical, and English School. For exposition and applications, see Sterling-Folker (2006). Three of these approaches-realist, liberal, constructivist-are applied to Asia by Acharya (2014, 59-89), Having asked whether Western theories have universal validity, Acharya concludes, 83: "The challenge for theoretical writings on Asian IR is to reflect on and conceptualize this dynamic, whereby scholars do not stop at testing Western concepts and theories in the Asian context, but generalize from the latter in order to enrich the hitherto Western-centric IR theory."

${ }^{3}$ This negative appraisal is approximately the position of Terry (2013); for a very different perspective, see Yi (2014).

${ }^{4}$ Koh remarked that the chairman of a large scale diplomacy conference "is both a choreographer and conductor of an orchestra." The conductor must lead the various structures within the orchestra on a variety of issues. Of course some players have their distinctive styles-as discussed by Cohen (2002) under the rubric of high and low context diplomacy. 


\section{GET TO YES}

Getting to Yes by the late Roger Fisher and William Ury offers a roadmap to negotiating mutually advantageous deals "without giving in." (Fisher and Ury 1991; for related works, Holdren 1998; Ury 1993/2007; Clemens 2010a). The authors recommended that each side assess and focus on its own deep interests. The wise policy maker will ask: "What is my side's best alternative to a negotiated agreement?" To reach an accord, empathy is essential. Each party needs to understand how the conflict and its possible resolution look from the other's vantage point. Also, what is the other side's best alternative to a negotiated deal?

Fisher and Ury disparaged "positional bargaining" because it can obscure the deepest interests of each participant. ${ }^{5}$ If interests conflict, Fisher and Ury recommended "principled negotiation"-an objective examination of the case based on the principles at stake. This approach makes sense for a boundary dispute arising from a new curve in a river formerly divided down the middle. But what if each party starts from a very different principle? What if one side seeks to prevent the entry of more powers into the nuclear-weapons club while its opponent demands weapons "equality"? What if one side pursues regime change while the other seeks to keep its existing power and privileges? What if one side presses for political and civil liberties while the other sees "order" as fundamental? Can the "getting to yes" approach succeed-not just in domestic disputes-but also in life-and-death confrontations such as those in Northeast Asia?

The "getting to yes" approach is prescriptive but it also helps us understand why negotiations have failed when the parties relied on positional bargaining or disagreed on the principles at stake.

\section{PRISONER'S DILEMMA, TIT-FOR-TAT, AND “GRIT”}

Calculating what they see as self-interest, the major players in Northeast Asia have often been myopic. They have behaved like players in a single round of game theory's Prisoner's Dilemma. Accused of a crime and prevented from communicating with each other, the best choice for each player seems to be sauve

\footnotetext{
${ }^{5}$ A positional bargainer might begin by demanding $\$ 1,000$ for her used car. If the potential buyer offers $\$ 500$, she might be willing to split the difference at $\$ 750$. But what if the seller must leave town tomorrow and the buyer refuses to bid higher than $\$ 500$ ? The seller's interest may require her to ignore her bargaining position and sell the car at any price-as happened to investment bank Bear Stearns in 2008 when compelled to sell its stock for $\$ 10$ a share rather than the recent value of $\$ 133$. ther remains silent. But if each follows this course, each is jailed. Thus, mutual defection leads to mutual punishment.
} 
qui peut-every player for him/herself-"defection" from any shared solidarity with each other by confessing to the crime. Since this is what narrow self-interest recommends, both players confess and both wind up in jail. Had each remained silent, the game rules would allow each to go free. Having "rationally" sought individual gain, each player suffers and loses the possibility of mutual gain. Enlightened self-interest would have counseled cooperation-joint refusal to confess--provided each prisoner acted to achieve an outcome good for each. ${ }^{6}$

The game theory exercise underscores the twin problems of communication and trust that bedevil all human relations. However the real world differs from PD in several ways. In the game, the two prisoners cannot communicate with each other and cannot be sure that one of them will not defect. In the real world players can usually communicate with each other, if only though muddied and broken channels, sometimes sending false signals to mask their intentions and capabilities. Usually there are more than two players--allies, foes, bystanderswhose responses and actions may shape the "game." Seldom are outcomes in world affairs decided by one round of play. Rather, the game goes on-with elements of continuity and change. Each round proves to be part of some larger game.

If the PD game is iterated, players (humans or computers) tend to learn. If one player defects or cooperates, so does the other in a sequence of "tit-for-tat." A policy of TFT echoes the ancient rule "an eye for an eye." But TFT can also mean "one good turn deserves another" or "one hand washes the other [eine Hand wâscht die andere]" for mutual gain. If PD is iterated, the best strategy for the long run is to follow a "nice" or "generous" version of TFT: If you play first, be nice. Afterwards mimic the other side. If your turn comes second, you should mimic the other player but be sure to reciprocate if he or she plays "nice."

North Korean diplomats have often called for a version of TFT. They have insisted on the principle: a word for a word, an action for an action. The South's Sunshine Policy, however, invited-and got--abuse by offering one-sided concessions in the hope of gradually transforming the relationship.

If the players embark on a nice version of TFT, the momentum of their words and deeds should take them into positive territory. The problem is that if one side seems to act aggressively, the positive momentum will not start or will be derailed. The players will then find themselves on a treadmill of mutual defection-as has happened often in U.S.-DPRK relations. North Korea often complained that Washington, after an agreement had been reached, raised the goal posts, while the Americans charged that Pyongyang ignored the goal posts. Thus, the North effectively killed the "Leap Day" agreement reached on February

\footnotetext{
${ }^{6}$ A player could achieve the very best outcome-freedom plus a reward-if he/or she defects and the other remains silent. But if each follows this course, each is jailed. Thus, mutual defection leads to mutual punishment.
} 
29, 2012 by launching a ballistic missile in April-an act that U.S. diplomats warned would be a deal-breaker, and was banned by UN Security Council resolutions (see, Revere 2012).

To break and then reverse a vicious cycle of escalating tensions, psychologist Charles E. Osgood in 1962 suggested a strategy of graduated reciprocity in tension-reduction (GRIT). One side, probably the stronger, should announce that it seeks to move step-by-step toward détente and better relations. The initiator of GRIT takes several small steps and pledges that, if reciprocated, larger steps will follow (Osgood 1962). To alter the momentum of mutual defection, one player must take a unilateral first step toward conciliation--even if the other side has just played tough. The initiator risks that its nice move will be ignored or abused. To guard against this possibility, the first steps toward détente should be limited and reversible. For example, U.S. officials could regularly call the "Democratic People's Republic of Korea" by its chosen name (as Kissinger did with the "People's Republic of China" in the early 1970s). ${ }^{7}$ The initiator should announce that its moves do not arise from weakness but from a deliberate strategy aimed at shifting from confrontation to cooperation. If the other side reciprocates with nice moves of its own, the process can escalate to more substantive concessions.

GRIT differs from TFT in two ways: The initiator does not mimic the tough steps of the other side but tries to start a process that breaks from mutual defection. If nice initiatives are reciprocated, the initiator's next actions should raise the quality of the interaction, graduating from low-risk, symbolic steps to more substantive moves.

An effort to develop GRIT confronts seven major challenges, overlapping and interacting so that it is nearly impossible to distinguish cause from effect, independent from dependent variable:

First, which side goes first? Osgood argued that the stronger party should do so, because it can better afford to take risks for peace. By this logic, the United States could initiate a dialogue with Pyongyang rather than vice versa. The stronger side can better afford to risk concessions, but it may ask, "Why forgo any advantage?" The mind frame of each actor can prove more decisive than the balance of power. When Mikhail S. Gorbachev launched a GRIT-like strategy toward the Reagan administration in the late 1980s, his side was the weaker-and more desperate for détente. Following the collapse of the Leap Day accord, neither Washington nor Pyongyang wanted to take the first step. The United States demanded that the DPRK demonstrate its willingness to demilitarize before six-party talks could resume. Pyongyang, for its part, rejected any pre-conditions and said that Washington needed to stop its hostile behavior.

${ }^{7}$ Obama in his first six years as president joined more than joint statements with other governments incorporating the acronym "DPRK." In more than one hundred of his own statements, he spoke of "North Korea." Data at http://www.presidency.ucsb.edu/ (April 11, 2014). 
Second, small steps may lead nowhere. To be safe, the initiator usually begins with symbolic gestures. The other side may interpret these as cheap tricks and not reciprocate. Neither side wishes to be fooled. In January and March 2014 the DPRK National Defense Commission proposed to the ROK what the North characterized as positive and conciliatory proposals. When they did not elicit a positve reponse, North Korean entities in April-May 2014 denounced President Park Guen Hue as a slut for Barack Obaama. Of course Pyongyang was responding to multiple pressure including another round of U.S.-ROK military exercises.

Third, the initiator may renounce GRIT before the other side absorbs the message and devises an appropriate response. The initiator cannot wait long if domestic critics attack its "giveaways."

Fourth, if the parties'assets are asymmetrical, it may be difficult to find a proportional concession. Between a superpower and North Korea, nearly all assets are asymmetrical.

Fifth, foes of détente or extraneous events in other realms can throw a monkey wrench that disrupts the process of tension reduction.

Sixth, bureaucratic inertia and vested interests can throttle GRIT. Purveyors of propaganda and "dirty tricks" may continue business as usual.

Finally, momentum may be hard to sustain. The first steps toward conciliation may come cheap, while further moves encounter profound obstacles and greater risks.

Is the strategy of GRIT naïve and infeasible? Not at all. It is a path to reconciliation that can both nourish and draw upon a willingness to create values for each party and not just claim them for oneself. This was essentially the path taken by John F. Kennedy and N.S. Khrushchev in 1963. The administration of U.S. President Richard M. Nixon used GRIT-like tactics to open a direct dialogue with Beijing in 1971-1972. Worried about a possible rebuff from China, however, Nixon and his national security adviser Henry Kissinger kept their overtures to Beijing secret. They departed from Osgood's recommendation that top leaders announce in advance their effort to change the game. But Zhou Enlai understood Kissinger's nuanced messsages and responded in kind (Clemens 2004).

It is unlikey that the leaders of the great powers have read academic literature about GRIT or "nice" ways to do TFT. Still, Soviet and U.S. leaders groped toward ways to temper mutual distrust and enmity. Short-lived thaws took place in 1955, 1958-1960, 1963-1964, 1968-1969, 1972-1973 and 1979. In the late 1980s, however, Soviet and U.S. leaders nearly put an end to the Cold War.

Efforts to reduce tensions on the Korean Peninsula have at times raised hopes for success only to reach an ugly impasse. In 1970 a U.S. Army lieutenant in the United Nations Command at Panmunjom told me how he had tried to improve the atmosphere within the conference room there. Instead of standing stiffly and glaring when a North Korean indicated that he wanted to pass, the American smiled and made way for him. Shortly thereafter, the American found himself 
surrounded by several North Koreans who began to jostle him. "Knuckle practice" nearly ensued. The North Koreans, it turned out, interpreted the lieutenant's conciliatory gesture as weakness. Obviously, true GRIT could not begin with gestures initiated by a mere lieutenant. For GRIT to work, the U.S. president or head of the UN team would need to announce a new strategy-and make sure that North Korean leaders and troops got the message.

But fake GRIT is also possible. Reacting to signs of U.S.-Chinese détente, leaders of North and South Korea smiled at each other and uttered declarations of good will in 1971-7972, only to show by word and deed in 1973 that each had been trying to deceive and undermine the other. The Park Chung-Hee regime in Seoul and that of Kim Il Sung in Pyongyang gave up all pretense of good will in 1973. They terminated their dialogue and stepped up clandestine efforts to develop nuclear weapons (Hong 2011; Clemens 2010b). The GRIT-like tactics of each side had not been sincere. Arrogant self-confidence ended up in a zero-sum struggle. ${ }^{8}$

The South Korean "Sunshine Policy" under presidents Kim Dae Jung and Roh Moo Hyun could have been an exemplar of GRIT if it had been reciprocated (Moon 2012; Lim 2012). The ROK government dragged its feet on some commitments made by Kim Dae Jung, but North Korean leaders treated both ROK presidents as patsies who could be milked for one-sided concessions. Critics faulted the policy for not insisting on reciprocal actions by the North. Ostensibly angered by South Korean rhetoric and by ROK-U.S. military exercises, Pyongyang shut down one of the last vestiges of the Sunshine policy, the Kaesong Industrial Park, in April 2013, only to call for its reopening a few months later.

The aborted North-South détentes of the early 1970s and early 2000s showed that even when direct communication could be facilitated by face-to-face meetings with a shared language, reasons for distrust remained. Each side had reason to agree with Hamlet's advice to his sister, "Best safety lies in fear."

\section{VALUE-CLAIMING VERSUS VALUE-CREATING FOR MUTUAL GAIN}

Unless each party can be persuaded to work for tension reduction and mutual gain, neither GRIT nor any other diplomatic technique can succeed. Negotiators may try to claim values (utilities of any sort) or to create values useful to each party (Raiffa 1982/2002; Lax and Sebenius 1986; Watkins 2006; Bazerman and Malhotra 2007; Friedman and Himmelstein 2008). ${ }^{9}$ Value-claiming is a

\footnotetext{
${ }^{8}$ http://www.wilsoncenter.org/document-collections (March 27, 2013).

${ }^{9}$ For additional references, see http://www.pon.harvard.edu/hnp/ (June 10, 2014); also Conflict Resolution Quarterly, Journal of Conflict Resolution, International Negotiation, and Negotiation Journal.
} 
distributive competition for larger shares of a limited supply of goods; while value-creating is an integrative bargaining process to expand supply. These alternatives generate three approaches to negotiation. Hard-line unilateralists see politics as a zero-sum contest in which one side wins and the other loses. Winwin optimists expect positive rewards for all parties. Conditional cooperators try to create values for mutual gain but take precautions lest other actors fail to reciprocate (Clemens 2004).

Value-creators see most situations as open-ended-as "variable-sum." This means that one or even both sides can lose (as in a nuclear war) but there is also a possibility-though no inevitability-of joint gains. So they look for ways to expand the pie to generate positive outcomes for each party. Unilateral gains are sometimes possible but are likely to be short-lived whereas mutual gains are more likely to endure.

Northeast Asia need not be trapped in a pattern of mutual defection. The key players could learn from Europe and North America where, after centuries of bloody fighting, deep networks of complex interdependence have made war virtually unthinkable. Narrow efforts to gain more land and resources, more influence and prestige have given way to a realization that cooperation nets greater benefits than zero-sum exploitation. This realization was catalyzed by the European Recovery Program, 1947-1951-planned and implemented for mutual gain.

Conditional cooperation and value-creating also helped to improve U.S.Soviet and U.S.-Chinese relations. Is it feasible to adapt this approach to resolve differences among the stake holders in Northeast Asia?

\section{HIGH CONTEXT DIPLOMACY AND THE “LINTON THESIS”}

How to induce reciprocity in relations between long-time antagonists, distrustful of one another and with different assets and worldviews, is deep problem. Culture-the basic values of a society and its way of life--is a matrix that conditions how policy makers and negotiators perceive the world and respond to signals. Negotiations are heavily shaped by whether participants embody a "high" or a "low context" approach to negotiations (Cohen 2002). Most Asians, including Koreans, are said to lean toward a high context style. They place great importance on the overall setting of negotiations. For Asians, a negotiated deal requires personal bonds between the negotiators. Low context Americans, by contrast, are said to focus on the bottom line and on abstract rules and laws, with little regard for cultural sensitivities and diplomatic niceties.

An American with vast experience in Korea, Stephen W. Linton, has identified the DPRK approach to negotiations as very high context: "From the North Korean 
perspective, human relations should never be made conditional on something else. Problems should be portrayed as annoying obstacles to what is most important: friendship between the highest levels of leadership....[Attempts] to meet leadership, resolve sensitive issues, and conclude agreements, all on a threeday trip to Pyongyang, sends the wrong message." Unlike many Westerners, Koreans do not see impersonal law as the framework for action but rather the personality behind the law. "Proof of interest at the highest level is paramount for giving the negotiating process legitimacy (Linton 1995)."10

What if Linton is correct that Koreans, unlike Westerners, do not see impersonal law as the framework for action? Personal ties might help negotiators reach a deal, but if law counts for so little, how long will the deal last? Linton replies that "what appears to Westerners as 'the rule of law' can look like the 'misrule of law' to North Koreans. They would rather focus on the 'intention' rather than the wording of agreements....Legalistic parsing of documents, accepted as a matter of course by Westerners, can look like insincere 'twisting', thereby undermining faith in the written word. North Koreans' search for personality behind law is thus a search for constancy-not just emotion." ${ }^{\prime 1}$

"More focus on atmospherics and relationships between principals would go a long way" in negotiating with North Koreans, says Linton-but only if U.S. officials take these relationships seriously. "Many Koreans note, however, that while Americans are quick to use first names and slap people on the back in a display of friendship, their 'true intentions' are often 'inscrutable', and they do not seem to take friendship itself that seriously." An apparent "obsession with being 'neutral' and 'fair'...can translate as a selfish reluctance to 'stand up for your friend'..."."

North Korean leaders have often proclaimed their desire to do business at the highest level with the United States. Kim Il Sung proved himself ready to deal when former president Jimmy Carter traveled to Pyongyang in 1994. Vice Marshal Jo Myong Rok visited Washington in October 2000 and urged President Bill Clinton to visit Kim Jong Il in Pyongyang. If he did so, the marshal said, all outstanding issues between the two countries could be resolved. Instead of the president, Secretary of State Madeleine Albright went to Pyongyang in November 2000 and thought she achieved an understanding with Kim Jong Il. She urged

${ }^{10}$ Having grown up in a Presbyterian missionary family in South Korea, Linton first visited North Korea in 1979 as an observer to an international table tennis meet. Later, while studying and teaching Korean religion at Columbia University, he met twice with DPRK leader Kim Il Song as an interpreter for Billy Graham. When the DPRK asked for assistance in 1995, Linton left Columbia and founded the Eugene Bell Foundation to coordinate shipments of donated food. In 1997 the DPRK Ministry of Public Health asked Linton to focus the organization's work on tuberculosis. See, Linton (2003); also http://www.eugenebell.org/ (March 14, 2014).

${ }^{11}$ Stephen W. Linton, e-mail to Clemens (November 8, 2009).

${ }^{12}$ Ibid. 
Clinton to go to North Korea and seal the deal (Albright 2003). When former president Clinton finally visited Pyongyang in June 2009, he was greeted warmly.

Showing himself less dedicated to meeting top leaders than his father, General Kim Jong Un (one year in the job) snubbed Google president Eric Schmidt and former New Mexico Governor Bill Richardson, long an interlocutor with the DPRK, when they traveled to Pyongyang in January 2013. The young general showed even less finesse when he suggested to basketball superstar Dennis Rodman to have Barack Obama give him a ring some time.

\section{A KOREAN WAY OF NEGOTIATING?}

Koreans can be abrasive-not only with adversaries but also with ostensible allies and fellow Koreans. North Koreans often appeared callous and grabby when dealing with their ostensible benefactors in the USSR and China. Even with Western and other foreign donors of humanitarian aid, DPRK officials are often rude and demanding.

Experience shows that when Koreans negotiate, whether from the South or the North, they are often tough with each other and practice all the varieties of kojip [stubborn intransigence]. Thus, one experienced U.S. diplomat pictured Koreans as "very direct and tough people." When South Koreans tried to open negotiations with PRC representatives in Hong Kong in the early 1980s, "they made quite a hash of this. They tended to demand things up front, and to use very blunt and insulting bargaining techniques, and to misunderstand the difference between things that needed to be done with a wink and a shrug and things that could be done explicitly. And so they were getting nowhere (Freeman 2001, 429-430)."

On balance, Pyongyang's behavior challenges any view that North Korea's diplomacy arises merely from a "high context" culture that requires a sort of feelgood atmosphere to nurture trust and smooth over differences. DPRK diplomacy seems to be driven by forces much deeper than a desire to maintain "face [cheymyon]" and nourish the "inner spirit [kibun]" of negotiations. One analyst says these qualities are basic to Korean culture--north and south, but he also catalogs a whole series of tough negotiating DPRK tactics meant to coerce, offend, manipulate, confound, and obstruct (Saccone 1994/2003/2006). The fist fights that occasionally break out in the ROK Diet also contradict any idea that Korean culture assures genteel behavior.

At times North Korean negotiators have seemed to play roles in "a theater of the absurd: Pyongyang promises, then procrastinates, then provokes, then pauses. After a long pause come new promises, and the cycle starts anew (House 1997)." An American based in Seoul perceives a "now-familiar cycle of North Korean provocation, American warnings, North Korea follow-through and American calls 
for more peace talks"-calls mocked by Pyongyang as abject surrender (Myers 2000).

Can these contradictory impressions be reconciled? Scott Snyder's 1999 book devotes an entire chapter to what Cohen would call the high context approach taken by North Koreans in negotiation (Snyder 1999; Saccone 2003/2006). North Koreans value punuigi [atmosphere] and kibun [good feeling]. If these are absent, North Koreans practice kojip [intransigence]-expressed in brinkmanship, cries of wolf, demands for unilateral concessions, bluffs and threats, manufactured deadlines, and threats to walk away from the negotiations. All this aims to create leverage out of weakness (Armstrong 2013). Also, before a deal is possible, the lead DPRK negotiator may need to show kosaeng [suffering] - proof for his bosses that he has done everything possible to extract the most possible concessions. Underlying the entire enterprise is "face." An American visitor to Pyongyang was told: "For us, saving face is as important as life itself (Snyder 1999)." When a U.S. diplomat asked his DPRK counterpart to be sure a U.S. condition for an accord was made clear to the top leader in Pyongyang, the North Korean demurred, saying, "I'd be shot if I did that."

Snyder argues that North Korea's crisis-oriented negotiation style manifests a pattern of drama and catastrophe. Rather than a linear process with a discrete beginning, middle, and end, Snyder suggests that that North Korea's dealings with the United States should be seen as a cycle in which issues are revisited, points reexamined, and interpretations redefined. Expanded, the process may include new issues and deeper mutual understanding.

Koreans may conclude business deals at a feast that celebrates a relationship rather than in some formal setting. "Good vibes" may set the stage for developing a personal and working relationship. But conviviality can also incubate corruption.

While Linton emphasizes face and feeling, and Snyder drama and catastrophe, each behavior may be part of a larger and quite distinctively "Korean" way of negotiating. Thus, a Washington insider on Korean affairs observed: "One has only to spend time working with a South Korean company to see how similar are these strands, and how they have their own internal logic. It is inordinately frustrating for outsiders who must deal with Koreans, because the mixture of bombast, face, stubbornness, and emphasis on context and good relations may seem quite puzzling. ${ }^{13}$ But it's all part of a whole that has an internal logic." This logic arises from the fact that "Korean culture is the most hierarchic in East Asia. As a result, when discussions between two 'equals' breaks down, it is a huge break, and also virtually impossible for them to back down or compromise from a stance, no matter how illogical that stance is--to do so is to lose all face

${ }^{13}$ This is one view, but the author knows a "Caucasian" American exporter of machinery who finds it easy to deal with South Koreans and difficult to come to terms with Europeans. 
and submit to the other side. In this context, a third party, usually of higher 'rank' is necessary to intervene and find a solution. Once relations are restored, great warmth and flexibility is possible by all sides, but approached in the wrong manner, this is impossible." These patterns of conflict and conflict resolution were evident in South Korean television dramas before the 1990s. . .

The Washington insider added that negotiations with North Korea began to record some progress in the second term of George W. Bush because, in contrast to previous years, some negotiators were "deeply experienced with Korea itself (not just East Asia or negotiating in general), and the expectations of what to expect from the North Koreans in terms of style were much clearer than before."

The legacy of Confucianism may also shape Koreans' negotiating behavior. Koreans are taught to show respect to elders. They believe that deference to superiors is proper but they also expect that it may also bring rewards-of equal or greater value. Indeed, elders are expected to take care of younger persons. But while it may be virtuous for a younger brother to give way to his older brother, or a wife to her husband, it could be wrong for a business or government agent to make a concession to another firm or country, because a concession might imply recognition of the other's superior standing. Accordingly, North Koreans often object to any sign of unequal treatment in negotiations with South Korea. Since the United States is so large and powerful, however, North Koreans may be more inclined to respect its authority.

\section{IMPLICATIONS OF INTERDEPENDENCE}

A wise policy must take account of growing interdependence across borders. Mutual dependence signifies mutual vulnerability--a relationship so close that moves by any party can harm or help the other. The realities of global interdependence reinforce the logic of a strategy aimed at creating values for all parties.

Interdependence is rarely symmetrical. North Korea occupies slightly more space than South Korea but possesses less than half the ROK population and just a fraction of its material wealth. The DPRK is far smaller and weaker than any of its other negotiating partners-the United States, China, Russia, and Japan. Still, the DPRK and each of these parties share not only vulnerabilities but also a potential for mutual gain. Such asymmetries are not unique. Actors on the global stage are seldom equal. Even the U.S. and Soviet "superpowers" had very different assets and liabilities. One was more than twice as rich; the other, twice as large. Still, Washington and Moscow recognized their shared needs and the utility of collaborating in many realms (Clemens 1990).

In our world of escalating interdependencies, an effective foreign policy 
needs to follow three axioms: First, those who make and carry out policy must develop and apply a "smart" mix of hard and soft power plus conversion power-the ability to apply them effectively. ${ }^{14}$

Second, each actor's deepest interests are more likely to be advanced by policies intended to create mutual gain with others than if they pursue valueclaiming policies aimed at unilateral gain. Exploiting others may achieve shortterm gains but will tend to boomerang over time so that the costs outweigh the benefits. The time in which exploitation could pay becomes ever shorter, thanks to modern communications and interdependence. Evolution shows that the capacity to cooperate is vital for species fitness. Of course a mutual gain strategy requires reciprocity. If any actor merely pockets the other's concessions and then asks for more, value-creating will be a losing strategy.

Third, the more that all actors communicate with each other and with their own publics, the greater the prospect of finding solutions useful to all sides. The most successful American foreign endeavor of all time, the Marshall Plan, was planned, organized, and conducted in full view. Both its inputs and outputs were mutual. The more complete the public discussion of policybased on accurate information, the lower the danger of counterproductive adventures such as the Iraq War. For a dictatorship, open discussion of the facts and policy alternatives may not be feasible, but even an authoritarian regime can profit from sharing its objectives, assets, and needs with foreign interlocutors. Without shared knowledge of each side's desiderata, their optimal an accommodation is unlikely.

The prospects for better mutual understanding are improved by the fact that, in today's world, countries communicate not only through their government officials but also through their unofficial representatives--rock stars, basketball players, evangelists, au pairs, bloggers, and ordinary tourists. We have not only Track 1-official diplomacy between governments, but also Track 2 or "private citizen" diplomacy. With North Korea we have also Track 1 1/2 diplomacy conducted by private or semi-private citizens. Thus, representatives of the Nautilus Institute have discussed energy issues with North Korean specialists while U.S. officials have observed and taken notes. ${ }^{15}$ Negotiations by business and commercial interests constitute a kind of Track 3 with some ability to

${ }^{14}$ Hard power is the ability to command or coerce others using military or economic assets; soft power is the ability to inspire or persuade others to act as you would like. Conversion power is needed to activate these assets and use them to shape others' behavior. See, Nye (2008). Many academic specialists thought that, of their number, Nye had the greatest influence on U.S. foreign policy.

${ }^{15}$ See, for example, http://www.nautilus.org/energy/2006/beijingworkshop/index.html (July 15, 2007). The Northeast Asia Peace and Security Network brings together nonproliferation specialists, regional security experts, and non-governmental organizations to analyze energy and other issues of peace and security in Northeast Asia. 
leapfrog political hang-ups.

The many forms of diplomacy now available contribute to a major hope for peace-relationships of complex interdependence. While interdependence could exist in just one area (e.g., vulnerability to nuclear attack), complex interdependence is marked by three features: first, the parties interact on many levels-not just at the summit (as among heads of state); second, their agendas touch many shared concerns with no clear hierarchy; and third, given these linkages, discord over any particular agenda item or items could never give rise to war (Keohane and Nye 2001). Where complex interdependence is strong, as in today's Europe, violence as a way to resolve disputes becomes unthinkable. However the ROK Sunshine Policy aimed to create such relationships with the DPRK but left a legacy of distrust and enmity. A growing structure of complex interdependence has begun to shape U.S.-Chinese relations but, for the present, is at most a mental image-a possible model---for U.S.-DPRK relations.

\section{IS THERE ANY VALUE TO THEORY?}

U.S. and North Korean diplomacy seemed to reach an impasse in Obama's second term. Also, North-South relations went from bad to worse. Beijing and Pyongyang maintained at most a façade of friendship. ${ }^{16}$ Did. all this mean that the theories discussed here were useless? No. Some theories do help explain diplomatic failures and suggest ways to avoid them. For example, GRIT explains why a second lieutenant's smile spawned conflict rather than harmony at Panmunjom. Professor Osgood's theory wisely suggests that, for tensionreduction to succeed, the strategy must be enunciated at the highest level. High context culture theory and the Linton thesis help explain why the brief trip of U.S. diplomat James Kelly to Pyongyang in October 2002 with an accusation and his rigid instructions (no side discussions of any kind, no socializing) virtually ended the Agreed Framework cooperation. ${ }^{17}$

No prescriptive theory can succeed unless it is earnestly and consistently implemented by all concerned parties. Unless all parties wish seriously to explore what a negotiated deal could accomplish, no prescriptive theory can move a mountain of intransigence. For us to say that a theory failed. Both Washington and Pyongyang would have to act as recommended by that theory

\footnotetext{
${ }^{16}$ Only when Moscow agreed in 2014 to forgive most of Pyongyang's debts going back many decades and to build a rail link from Siberia into a North Korean port did DPRR-Russian relations tick up

${ }^{17}$ Secretary of State Colin Powell was angry that his turf had been invaded by talking point instructions to Kelly drafted by National Security Council and White House hard liners. See, Rice (2011), $161-162$
} 
and do so for some time. If both sides really want a deal and it is relatively simple, they may not need any theory to light their way. But if things are tense, as in U.S.-Soviet relations in the early 1980s, following an insightful recipe may remove blockages and hasten progress.

Of course the parties must be in synch and the timing must be right. It appeared in 2011 that Washington and Pyongyang were ready to exchange food for arms control. Had the deal been formalized and implemented promptly, it might have been endured. Food deliveries could have begun and DPRK plans for a missile launch put on hold. Instead, momentum was interrupted by the death of Kim Jong il in November 2011. Terms were not formalized until February 29, 2012. By that time, however, a new "General" was trying to look both tough and filial. Preparations for the missile launch were nearly complete. The launch took place in April on the centennial of his grandfather's birth. As Washington saw it, Kim Jong Un had spiked the deal.

Like Christianity and other faiths, none of the theories discussed here has received a fair trial. Given their failures or relative successes, we can better understand the historical record and what approaches might be more fruitful in future interactions.

\section{REFERENCES}

Acharya, Amitav. 2014. “Thinking Theoretically about Asian IR.” In David Shambaugh and Michael Yahuda eds., International Relations of Asia, 2nd ed. Lanham MD: Rowman \& Littlefield, 59-89.

Albright, Madeleine Korbel. 2013. Madam Secretary: A Memoir. New York: Harper Collins.

Armstrong, Charles K. 2013. Tyranny of the Weak: North Korea and the World, 1950-1992. Ithaca NY: Cornell University Press.

Bazerman, Max and Deepak Malhotra. 2007. Negotiation Genius: How to Overcome Obstacles and Achieve Brilliant Results at the Bargaining Table and Beyond. New York: Bantam.

Clemens, Walter Jr. 1990. Can Russia Change? The USSR Confronts Global Interdependence. New York: Routledge. . 2004. Dynamics of International Relations: Conflict and Mutual Gain in an Era of Global Interdependence, 2nd ed. Lanham MD: Rowman \& Littlefield. . 2010a. Getting to Yes in Korea. Foreword by Gov. Bill Richardson. Boulder CO: Paradigm 2010 and in Korean, Seoul: Hanul. . 2010b. "North Korea's Quest for Nuclear Weapons: New Historical Evidence." Journal of East Asian Studies 10(1), 127-154. 
. 2013. Complexity Science and World Affairs. Albany: State University of New York Press.

Cohen, Raymond. 2002. Negotiating Across Cultures: International Communication in an Interdependent World, Rev ed. Washington, DC: United States Institute of Peace.

Fisher, Roger and William Ury. 1991. Getting to Yes: Negotiating Agreement Without Giving In, 2nd ed. New York: Penguin, 1991.

Freeman, Charles W. 2001. Interview in Nancy Bernkopf Tucker ed., China Confidential: American Diplomats and Sino-American Relations, 19451996. New York: Columbia University Press, 429-430.

Friedman, Gary and Jack Himmelstein. 2008. Challenging Conflict: Mediation Through Understanding. Chicago: American Bar Association Section on Dispute Resolution.

Gomà Pinilla, Daniel. 2004. "Border Disputes between China and North Korea." China Perspectives 52. Accessed at http://chinaperspectives.revues.org/ document806.html (March 31, 2009).

Holdren, John P. 1998. Getting to Zero: Is Pursuing a Nuclear-weapon-free World Too Difficult? Too Dangerous? Too Distracting? Cambridge, MA: Belfer Center for Science and International Affairs, Harvard University, 1998.

Hong, Sung Gul. 2011. "The Search for Deterrence: Park's Nuclear Option.” In Byung-Kook Kim and Ezra F. Vogel eds., The Park Chung Hee Era: The Transformation of South Korea. MA: Harvard University Press, 483-510.

House, Karen Elliot. 1997. "Let North Korea Collapse.” Wall Street Journal (February 21), A14.

Keohane, Robert O. and Joseph S. Nye. 2011. Power and Interdependence, 4th ed. Boston: Longman.

Lax, David A. and James K. Sebenius. 1986. The Manager as Negotiator: Bargaining for Cooperative and Competitive Gain. New York: The Free Press.

Lim Dong-won. 2012. Peacemaker: Twenty Years of Inter-Korean Relations and the North Korean Nuclear Issue. Stanford CA: Walter H. Shorenstein Asia-Pacific Research Center.

Linton, Stephen W. 1995. "Approach and Style in Negotiating with the D.P.R.K." Lecture, Center for Korean Research, Columbia University (April 6). . 2003. "Testimony before the Senate Foreign Relations Committee." on East Asian and Pacific Affairs (June 5). . 2009. e-mail to author (November 8) eds.

Minelli, Alessandro and Giussepi Fusco. 2008. Evolving Pathways: Key Themes in Evolutionary Biology. Cambridge, UK: Cambridge University Press.

Moon, Chung-In. 2012. The Sunshine Policy: In Defense of Engagement as a 
Path to Peace in Korea. Seoul: Yonsei University Press.

Myers, B. R. 2000. "To Beat a Dictator, Ignore Him.” New York Times (April 1). Nye, Joseph S. Nye. 2008. The Powers to Lead. New York: Oxford University Press.

Osgood, Charles E. 1992. An Alternative to War or Surrender. Urbana: University of Illinois Press.

Rice, Condoleezza. 2011. No Higher Honor: A Memoir of My Years in Washington. New York: Crown, Random House.

Raiffa, Howard. 1982. The Art and Science of Negotiation. Cambridge: Harvard University Press.

Raiffa, Howard et al. 2002. Negotiation Analysis: The Science and Art of Collaborative Decision Making. Cambridge: Harvard University Press.

Revere, Evans J. 2012. "Tough Challenges, Hard Choices: Dealing with North Korea after the Collapse of the Leap Day Agreement.” New York: National Committee on American Foreign Policy (June 2012). Accessed at www. ncafp.org/ncafp/wp-content/uploads/2012/07/Revere-Tough-Challenges-N-Korea-Final.pdf (February 28, 2014).

Roehrig, Terence. 2008. "Korean Dispute Over the Northern Limit Line: Security, Economics, or International Law?” Maryland Series in Contemporary Asian Studies. School of Law, University of Maryland.

Rubin, Alfred P. 2003. "Humanitarian Intervention and International Law." In Aleksandar Jokic ed., Humanitarian Intervention: Moral and Philosophical Issues. Peterborough, Canada: Broadview, 109-121.

Sebenius, James K. and Laurence A. Green. 2014. "Tommy Koh: Background and Major Accomplishments of the 'Great Negotiator, 2014'." Harvard Business School Working Paper 14-049 (February 13).

Saccone, Richard. 1994. The Business of Korean Culture. Elizabeth NJ: Hollym . 2003. Negotiating with North Korea. Elizabeth NJ: Hollym. . 2006. Living with the Enemy: Inside North Korea. Elizabeth NJ: Hollym.

Snyder, Scott. 1999. Negotiating on the Edge: North Korean Negotiating Behavior. Washington DC: United States Institute of Peace.

Sterling-Folker, Jennifer ed. 2006. Making Sense of International Relations Theory. Boulder, CO: Lynne Rienner.

Suh, Jae-Jung. 2010. "Race to Judge, Rush to Act." Critical Asian Studies 42(3), 403-424.

Terry, Sue Mi. 2013. "North Korea's Strategic Goals and Policy towards the United States and South Korea." International Journal of Korean Studies $17(2), 63-92$.

Ury, William. 1993. Getting Past No: Negotiating Your Way from Confrontation to Cooperation, Rev ed. New York: Bantam. . 2007. The Power of a Positive No: How to Say No and Still Get to Yes. 
New York: Bantam, 2007.

Van Dyke, Jon M. et al. 2003. "The North/South Korea Boundary Dispute in the Yellow (West) Sea." Maritime Policy 27(2), 143-158.

Watkins, Michael. 2006. Shaping the Game: The New Leader's Guide to Effective Negotiating. Boston: Harvard Business School Press.

Yi, Yurim. 2014. "Confrontation and Engagement in Relations Between the DPRK and the United States, 1991-2011." Ph. D. dissertation, Boston University. http://www.nautilus.org/energy/2006/beijingworkshop/index.html (July 15, 2007). http://www.wilsoncenter.org/document-collections (March 27, 2013). http://www.eugenebell_org/ (March 14, 2014). http://www.presidency.ucsb.edu/ (April 11, 2014). http://www.pon.harvard.edu/hnp/ (June 10, 2014).

[Received March 31, 2014; Revised May 6, 2014; Accepted J uly 2, 2014] 